International Journal of Economics, Business and Accounting Research (IJEBAR)

Peer Reviewed - International Journal

Vol-3, Issue-3, 2019 (IJEBAR)

E-ISN: 2614-1280 P-ISSN 2622-4771

http://jurnal.stie-aas.ac.id/index.php/IJEBAR

\title{
PREPARING THE ASEAN ECONOMIC COMMUNITY (MEA) WITH THE DEVELOPMENT STRATEGY OF SMALL AND MEDIUM ENTERPRISES (UMKM) TO GET BUSINESS CREDIT IN KELURAHAN CIBADUYUT BANDUNG
}

\author{
Dewi Untari ${ }^{1}$, Dewi Endah Fajariana ${ }^{2}$ Muchamad Ridwan $^{3}$ \\ ${ }^{1,2,3}$ Politeknik Kridatama Bandung, STKIP Panca Sakti \\ E-mail:dew11untari@gmail.com
}

\begin{abstract}
From the results of interviews and preliminary observations that the development of Small and Medium Enterprises is essentially a shared responsibility between the government and society. In order to support the empowerment and development of Micro, Small and Medium Enterprises, especially in encouraging the distribution of credit to Micro, Small and Medium Enterprises in Cibaduyut Urban Village, for the development of Micro, Small and Medium Enterprises in Cibaduyut Village, Bandung, the strategies included in the first Bank Partner Financial Consultants in fostering and mentoring Micro Small Enterprises and Medium prospects who apply for business loans; second, socializing profit sharing or venture capital financing; third Increasing the participation of credit guarantee institutions for Micro, Small and Medium Enterprises and prospects who are faced with collateral requirements. It is expected that with the implementation of the above strategies, Micro, Small and Medium Enterprises will no longer experience difficulties in the submission of business capital loans from Credit Distribution Agencies. From each solution above, it is building and mentoring Micro and Small and Medium Enterprises, prospects who will apply for business loans. The results of the study showed that the community in the Cibaduyut Village with the optimization of the role of the Bank Partner Financial Consultant (KKMB), the requirements and procedures established by the credit channeling institutions, were no longer an obstacle for Micro and Small Businesses in obtaining business capital loans. The success of this approach will be seen from the increasing number of bankable Micro, Small and Medium Enterprises and obtaining business capital loans, and having a Bank Partner Financial Consultant (KKMB) operating on a business (mutually beneficial) basis so that it can finance itself.
\end{abstract}

Keywords $\quad$ : Economic Growth, Creative Economy, Entrepreneurship, Culinary Tourism

\section{Introduction}

Micro small and Medium Enterprises (UMKM) is a business actor that role in various business fields, that touches the interests of the community. Based on BPS data (2015), the number of small and medium enterprises (UKM) reached 57.9 million. In 2017 UMKM made a significant contribution to employment absorption, that is 97.30 percent. Meanwhile, the contribution of UKM to Gross Domestic Product (GDP) was 58.92 percent. In 2016, President Jokowi stated that UMKM have high durability, will be able to sustain the country's economy, even during the global crisis. 
International Journal of Economics, Business and Accounting Research (IJEBAR)

Peer Reviewed - International Journal

Vol-3, Issue-3, 2019 (IJEBAR)

E-ISN: 2614-1280 P-ISSN 2622-4771

http://jurnal.stie-aas.ac.id/index.php/IJEBAR

UMKM have become the backbone of the Indonesian and ASEAN economies. Around 88.8-99.9\% of businesses in ASEAN are UMKM with employment reaching 51.7-97.2\%. Therefore cooperation for the development and resilience of UMKM needs to be prioritized. In addition to the Bank, many BUMN and private companies participate to help increase UMKM in Indonesia.

In the process of Indonesia's economic recovery, the UMKM sector has a very strategic and important role that can be viewed from various aspects. First is to reduce poverty. Second, to prepare for the ASEAN Economic Community (AEC) which has been implemented since 2016. This of course requires the UMKM businessman to be able to compete with entrepreneurs from other ASEAN countries. Therefore full support from the government, big businessman and the community are needed to boost the development of UMKM so that not many collapse.

One of the efforts to develop UMKM to survive in the national economy is done by encouraging the provision of business capital loans to UMKM. From the banking point of view, providing credit to UMKM is beneficial for the bank concerned. First, the level of congestion is relatively small. This is mainly due to the higher level of compliance of small business customers compared to large business customers. Second, providing credit to UMKM encourages the spread of risk, because lending to small businesses with a small nominal credit value allows banks to increase the number of their customers, so that credit is not concentrated in one particular business group or sector. Third, UMKM credit with a relatively larger number of customers will be able to diversify the loan portfolio and spread the risk of lending. Fourth, credit interest rates at market interest rates for small businesses are not a major problem, so as to allow credit providers to obtain adequate interest income. Experience so far shows that the availability of funds at the right time, in the right amount, the right target and with a simple procedure are more important than cheap interest or subsidies.

Based on Rahmana (2012: 19) the development strategy of UMKM in Indonesia consists of (a) maintaining and improving product quality, (b) improving Human Resource competencies, (c) optimizing the use of technology, and (d) increase cooperation with suppliers of raw materials. On the basis of this and several existing problems, then the title of the research is The Development Strategy of UMKM in Getting Business Loans in Cibaduyut Village, Bandung in 2017.

Strategy is a large scale plan that has a far-reaching future range and is defined in such a way as to enable the organization to interact effectively with its environment in conditions of competition which are all directed at optimizing the achievement of objectives with the various objectives of the organization concerned.

Chandler in Anoraga. (2004: 339) strategy is the long-term goals and objectives of a company, and the direction of action and the allocation of resources needed to achieve those goals and objectives. Strategy is the power of resources, capabilities and internal core competencies to achieve company goals in a competitive environment. With regard to winning the battlefield of competition and gaining global leadership, indirect strategic objectives mean the organization's resources, capabilities and core competition. When built effectively, the goal of the strategy can make people do things in ways that were previously considered impossible. In relation to the problem of strategy, the strategy can be defined as a program to determine and achieve organizational goals and implement its mission. The meaning of the strategy is that managers play an active role, conscious and rational in formulating organizational strategies. In a changing environment, this view is applied more. Strategy can also be defined as a pattern of responses or organizational response to their environment at all times. In this definition, every organization must 


\section{International Journal of Economics, Business and Accounting Research (IJEBAR) \\ Peer Reviewed - International Journal \\ Vol-3, Issue-3, 2019 (IJEBAR) \\ E-ISN: 2614-1280 P-ISSN 2622-4771 \\ http://jurnal.stie-aas.ac.id/index.php/IJEBAR}

have a strategy, even though the strategy has never been formulated explicitly. This view is applied to managers who are relative who only respond and adapt to the environment passively when needed. The goal of the strategy is when all employees and levels of the company are committed to achieving specific and significant performance criteria. Some argue that the goal as a strategy gives employees the only valuable goal for business and personal commitment to shift the best position, or remain the best in the world. The purpose of the strategy has been effectively formed when people believe with passionate about their products and industry. and when they fully focus on the company's ability to overcome its competitors.

In connection with business development, this depends on the ability of the entrepreneur and the manager in his business every day. This is like what was stated by Kellogg (in Moekijat, 2001: 20) that development as a change in the person who allows the person to work effectively.

According to Hafsah (2000: 198) development is an effort carried out by the government, the business world, and the community through the provision of guidance and reinforcement assistance to grow and enhance the ability of small business enterprises to become strong and independent businesses. Meanwhile, according to Mangkuprawira (2004: 135) states that development is an effort to increase knowledge that may be used immediately or often for future interests. Furthermore, Yoder in Moekijat, (2001: 20) explained that development is every effort to improve the implementation of current and future work, by providing information influencing attitudes or increasing skills.

In the Indonesian economy, MSMEs are the business group that has the largest number and is proven to be resistant to various kinds of shocks to the economic crisis. The business criteria included in Micro Small and Medium Enterprises are regulated in the legal umbrella. Based on Law Number 20 of 2008 concerning Micro, Small and Medium Enterprises (UMKM ) there are several criteria used to define the definition and criteria of Micro, Small and Medium Enterprises. According to Rahmana (2008), several institutions or agencies even provide their own definitions for Small and Medium Enterprises (UKM), including the Ministry of Cooperatives and Small and Medium Enterprises (Menegkop and UKM), Central Bureau of Statistics (BPS), Minister of Finance Decree No. 316 / KMK.016 / 1994 dated June 27, 1994. The definition of UKM tell varies from one another. According to State Minister for Cooperatives Small and Medium Enterprises (Menegkop and UKM), that what is meant by Small Business (UK), including Micro Enterprises (UMI), is a business entity that has net assets of no more than Rp. 200,000,000, excluding land and building of business premises, and has annual sales of no more than Rp. 1,000,000,000. Meanwhile, Medium Enterprises (UM) are business entities owned by Indonesian citizens who have a net worth greater than Rp. 200,000,000. to Rp 10,000,000,000, excluding land and buildings. The Central Bureau of Statistics (BPS) provides a definition of UKM based on the quantity of labor. Small businesses are business entities that have a workforce of 5 to 19 people, whereas medium business is a business entity that has a workforce of 20 s.d. 99 people. Based on the Decree of the Minister of Finance No. 316 / KMK.016 / 1994 dated June 27, 1994, small businesses are defined as individuals or business entities that have carried out activities / businesses that have sales / turnover per year of a maximum of Rp. 600,000,000 or high assets / assets IDR 600,000,000 (excluding land and buildings occupied) consists of (1) business entities (Fa, CV, PT, and cooperatives) and (2) individuals (craftsmen / home industry, farmers, ranchers, fishermen, forest encroachers, miners, merchants of goods and services). 


\section{International Journal of Economics, Business and Accounting Research (IJEBAR) \\ Peer Reviewed - International Journal \\ Vol-3, Issue-3, 2019 (IJEBAR) \\ E-ISN: 2614-1280 P-ISSN 2622-4771 \\ http://jurnal.stie-aas.ac.id/index.php/IJEBAR}

Every human being certainly has the instinct or desire in his life to try to achieve what is aspired. To achieve that desire, humans always try to achieve a better life. In this effort humans can establish various kinds of businesses that get success.

In fulfill human needs, business can lead to a business world that creates goods and services. According to Hornby Encyclopedia (2000: 402) effort is a particular activity that a group of people organize in order to achive something. That is, business is a special activity organized by a group of people to achieve a goal or something. According to Saparudin (2003: 1) states that business is an activity carried out by individuals or groups to earn income with the aim of obtaining profits.

In (www.bappekab.sidoarjokab.go.id) the definition of small business is clearly stated in Law No. 9 of 1995, which states that Small businesses are businesses with a net worth of at most Rp. 200 million (not including land and building of business premises) with annual sales of a maximum of Rp. 1,000,000,000. From the definition above it can be concluded that business is an activity which includes production activities, and distribution by using energy, mind and body to achieve a goal. Starting from the definition above so researcher can take a conclusion that Business development is a way or process to improve current and future work by increasing business expansion and the quality and quantity of production from economic activities by moving the mind, energy and body to achieve a specific goal.

According to Sri Winarni (2006) In general, small businesses have characteristics such as the following: (1) Usually in the form of an individual business and not a corporate legal entity, (2) Aspects of business legality are weak, (3) Organizational structure is simple with a non standard division of labor, (4) Most do not have financial statements and do not make a separation between personal wealth and company wealth, (5) Low quality management and rarely have a business plan, (6) The main sources of business capital are private capital, (7) Human Resources (HR) are limited, (8) The owner has a strong inner bond with the company, so that all the obligations of the company are also the obligations of the owner.

The Central Bureau of Statistics (2003) in Sri Winarni (2006) identifies common problems faced by UMKM are (1) Lack of capital, (2) Difficulties in marketing, (3) Strict business competition, (4) Difficulties in raw materials, (5) Lack of technical production and expertise, (6) Lack of Managerial skills, (7) Lack of financial management knowledge, and (8) unfavorable business climate (permits, rules / regulations). The results of the collaboration of the State Ministry of KUKM and BPS (2003) in Sri Winarni (2006) informed that SMEs experiencing business difficulties were $72.47 \%$, the remaining $27.53 \%$ had no problems. Of the $72.47 \%$ who experienced business difficulties, the identified difficulties were (1) Capital 51.09\%, (2) Marketing 34.72\%, (3) Raw materials $8.59 \%$, (4) Employment $1.09 \%$, (5) Distribution of transportation $0.22 \%$ and (6) Others $3.93 \%$. The dominant percentage of difficulties faced by UMKM mainly includes capital difficulties $(51.09 \%)$. Furthermore, it is stated that in overcoming the difficulties of capital it is known that $17.50 \%$ of UKM increase their capital by take a loan from banks, the remaining $82.50 \%$ did not make loans to banks but to non-bank institutions such as Savings and Loan Cooperatives (KSP), individuals, families, venture capital, others.

While the problems faced by UMKM in obtaining business capital loans include (1) difficult submission procedures $30.30 \%$, (2) Not interested in $25.34 \%$, (3) UMKM do not have collateral $19.28 \%$, (4) UMKM who do not know the procedure $14.33 \%$, (5) High interest rates $8.82 \%$, (6) Proposals rejected (1.93\%). 
International Journal of Economics, Business and Accounting Research (IJEBAR)

Peer Reviewed - International Journal

Vol-3, Issue-3, 2019 (IJEBAR)

E-ISN: 2614-1280 P-ISSN 2622-4771

http://jurnal.stie-aas.ac.id/index.php/IJEBAR

According to Sri Winarti (2004) by considering the important role of UMKM in various aspects of the economy and in the effort to accelerate the recovery of economic activities, Bank Indonesia provides support in the development of UMKM. Bank Indonesia's support also includes encouraging the recovery of the banking intermediary function and creating healthy banking conditions.

In order to support the empowerment and development of UMKM, especially in encouraging credit distribution to UMKM, Bank Indonesia's efforts include, among others, the application of credit policies, the provision of technical assistance to UMKM through Bank Partner Financial Consultants, research on financing patterns for UMKM, provision of small business financing information systems and provision of technical assistance.

People's business loans, Which is then abbreviated as KUR, are loans or financing to Micro, Small, Medium Enterprises and Cooperatives (UMKM-K) in the form of providing working capital and investment supported by guarantee facilities for productive businesses. KUR is a program planned by the government but the source of the funds comes entirely from bank funds. The government provides guarantees against the risk of KUR by $70 \%$ while the remaining $30 \%$ is borne by the implementing bank. KUR guarantees are given in order to increase UMKM-K access to financing sources in order to encourage national economic growth. KUR is distributed by 6 implementing banks, namely Mandiri, BRI, BNI, Bukopin, BTN, and Bank Syariah Mandiri (BSM).

The purpose of the KUR program is to accelerate the development of economic activities in the real sector in order to overcome and alleviate poverty and expand employment opportunities. In more detail the objectives of the KUR program are as follows: first, accelerate the development of the real sector and empowerment of Micro, Small, Medium Enterprises and Cooperatives (UMKMK); second, Increase access to finance and develop UMKM \& Cooperatives to Financial Institutions; third As an effort to overcome or alleviate poverty and expand employment opportunities.

Andriani's research (2008) on "Analysis of factors influencing the distribution of micro, small and medium credit in Indonesia". The results of this study indicate that in the long run the distribution of micro, small and medium credit is significantly affected by Gross Domestic Product (GDP), credit interest rates, credit capacity and Loan Performing Loans (NPL), where GDP has a positive effect while credit interest rates, credit capacity and NPL have a negative effect. Fitria Sari Research (2011) "The Role of Savings and Loans Cooperatives in the Development of Agribusiness UMKM in Bogor (Case Study of Kospin Jasa Bogor)". The results of this study indicate that there is an increase in income received by UMKM before and after receiving credit, total revenue increased by $\mathrm{Rp} 712,102,500$ before credit and became Rp 1,803,206,000 after credit. Research Audrey Julianus Pinem (2011) "Implementation of People's Business Credit in Developing Small Businesses (Study on PT Bank Rakyat Indonesia (Persero) Tbk". The results of this study indicate that the implementation of people's business loans by Bank Rakyat Indonesia has been going well and is able to develop small businesses, this is seen from the policies that support the implementation of KUR, capacity, and facilities provided to support the implementation of KUR, ease of procedure or administrative process, having quality human resources, and good communication between banks and the community. 
International Journal of Economics, Business and Accounting Research (IJEBAR)

Peer Reviewed - International Journal

Vol-3, Issue-3, 2019 (IJEBAR)

E-ISN: 2614-1280 P-ISSN 2622-4771

http://jurnal.stie-aas.ac.id/index.php/IJEBAR

\section{Method}

This research was carried out on Cibaduyut I street, Cibaduyut Village, Cibaduyut Village, Bojongloa Kidul District, Bandung City, West Java. The method used in this research is qualitative method. Qualitative research methods are research methods based on the philosophy of postpositivism, used to examine the condition of natural objects, where the researcher is a key instrument, Data source sampling is done purposively and snowball, collection techniques with triangulation (combination) and data analysis are inductive / qualitative and the results of qualitative research emphasize the meaning rather than generalization.

The research subject is all UMKM in Cibaduyut Village, Bandung Year 2017. In the preparation of this study, the authors conducted data collection conducted to obtain information and analyze data so that the data can provide information for the authors' research.

\section{Results And Discussion}

\subsection{Development of UMKM in Getting Credit}

From the results of data collection and looking at the explanation above, it can be said that the difficulties faced by UMKM are: (a) Limitations of Business Capital; (b) Soaring prices of raw materials and auxiliary materials due to plans to increase basic electricity tariffs; (c) limited technical design knowledge such as aesthetics, production technology, market trends and others; (d) the correct marketing management has not been implemented; (e) The quality of human resources is still low so that the leadership of the company has not been able to apply production management appropriately.

While the basic problem that is generally faced by UMKM in obtaining business capital is due to difficult submission procedures, lack of collateral, ignorance about procedures and high interest rates.From the several problems mentioned above, the only internal problem is ignorance about the procedure, while other factors are external factors (creditor side). If viewed from the side of creditors (financiers or financing institutions), to protect credit risk, demanding business activities that are carried out with the principles of modern management, official business licenses and collateral. The difference in perspective between the problems faced by UMKM and the conditions that must be adhered to by credit channeling institutions is the fundamental reason why UMKM still find it difficult to obtain business capital loans.

The development of UMKM is essentially a shared responsibility between the government and society. By looking at the problems faced by UMKM, the following should be pursued in the future:

\subsection{Optimizing the Role of Bank Partner Financial Consultants (KKMB)}

Bank Partner Financial Consultants (KKMB) are institutions or parts of institutions that provide business development services in order to improve the performance of Micro, Small and Medium Enterprises (UMKM). The institution is a legal entity and not a financial institution and can get a fee from its services. Services provided are consulting services in terms of management / financial analysis so that partnerships occur with banks or the occurrence of bank funds distribution to these UMKM. In this case, including assistance when preparing a credit proposal, connecting to a financing institution / bank and monitoring from the time of disbursement of credit to repayment of credit according to the agreed period of time. The function and responsibility of KKMB is to foster and develop UMKM. 
International Journal of Economics, Business and Accounting Research (IJEBAR)

Peer Reviewed - International Journal

Vol-3, Issue-3, 2019 (IJEBAR)

E-ISN: 2614-1280 P-ISSN 2622-4771

http://jurnal.stie-aas.ac.id/index.php/IJEBAR

Coaching here is meant to be a unified process which includes three elements namely : growing, maintaining and developing. The implementation process of KKMB coaching is carried out in a participatory manner, that everything related to coaching (material, methods etc.) must always rely on the needs of UMKM, therefore the working relationship between KKMB and UMKM is not as superiors and subordinates or the relationship between coaches and those who are coached. The relationships that are established are parallel and KKMB here acts as a motivator for UMKM. The form of coaching and development activities here is to provide assistance to MSMEs by providing technical assistance in the form of training according to needs, direction and consultation. To carry out these activities a KKMB in its implementation in the field is guided by the following steps:

a. Identify the prospective UMKM customers in Cibaduyut Village

b. Determine the group when obtaining prospective micro customers in the context of efficiency;

c. Prepare a credit proposal (micro business) or business feasibility (small and medium business);

d. Connecting these MSME customers with banks;

e. Monitoring and mentoring post credit acceptance;

It is expected that with the optimization of the role of $\mathrm{KKMB}$, the requirements and procedures set by the credit channeling institutions are no longer an obstacle for UMKM in obtaining business capital loans. The success of this approach will be seen from the increasing number of bankable UMKM and obtaining business capital loans, and the KKMB can operate on a business (mutually beneficial) so that it can finance itself.

\subsection{Socializing the Financing Profits Sharing Pattern or Venture Capital Financing}

For some UMKM that feel burdened with high interest rates, business capital needs can be submitted to financial institutions that apply a pattern of cooperation with profit sharing. Where is the return given by UMKM in accordance with the results obtained by UMKM at that time so that UMKM is not burdened with high interest rates. Financing institutions that implement profit sharing patterns are finance companies with venture capital financing and the concept of pure profit sharing or managed profit sharing. In terms of characteristics of Venture Capital that are Gain Risk (tend to be more willing to take risks), This financing has a looser procedure and prioritizes the prospects and business potential of UMKM in its development. This financing can be done in the short and long term (maximum 4 years). Venture Capital Financing does not only channel funds from shareholders and bank loans, but also distributes government program funds at rates that are cheaper than commercial credit rates. The program funds distributed by Venture Capital companies include LPDB funds (Revolving Fund Management Institution) and PKBL Funds (Partnership Program for Community Development) from PT. Bahana Artha Ventura and LPEI (Indonesian Export Management Agency) It is expected that by promoting the socialization of venture capital financing, UMKM that have problems in terms of credit interest still get business capital loans in the form of joint financing of profit sharing patterns or LPDB and PKBL program credits.

\subsection{Increase The Participation of Credit Guarantee Institutions}

Another alternative that can be used to overcome UMKM credit problems is a credit guarantee scheme. Under the scheme, the Bank and the Guarantor Company make a credit guarantee cooperation agreement. UMKM that need additional capital from credit channeling agencies submit guarantees to the Guarantor Company and apply for credit from the Bank. If the results of the 
International Journal of Economics, Business and Accounting Research (IJEBAR)

Peer Reviewed - International Journal

Vol-3, Issue-3, 2019 (IJEBAR)

E-ISN: 2614-1280 P-ISSN 2622-4771

http://jurnal.stie-aas.ac.id/index.php/IJEBAR

feasibility analysis, the business is declared feasible, but feasible from the banking point of view due to insufficient collateral (not bankable), then the bank submits guarantees to the Guarantor Company. Furthermore, the Guarantor Company will conduct a feasibility analysis. If the Credit is declared eligible to be guaranteed, the Guarantor Company will provide guarantees to small businesses that are stated in the form of a Guarantee Certificate. For the guarantee provided, small businesses that are guaranteed must pay a guarantee fee to the Guarantor Company. If a credit is guaranteed to be congested, the Guarantor Company will check, whether the existing conditions meet the requirements and conditions agreed by the Guarantor Company with the Bank. If all conditions have been met, the Guarantor Company will make a claim payment. Furthermore, the Guarantor Company is entitled to receive subrogation receivables in the amount of the guaranteed credit portion. After the claim payment is made, the Bank still has to carry out the collection until the debt is paid off. The billing proceeds are divided proportionally between the Guarantor Company and the Bank in accordance with the percentage of credit guarantee. With the credit guarantee, then:

a. Submission of credit by small businesses that previously did not meet banking requirements became bankable, so that UMKM could develop their businesses.

b. The Bank's risk is reduced, because some have been transferred to the risk of the Guarantor Company. With the fulfillment of sufficient collateral and reduced risk, the likelihood of rejection of the loan proposal becomes smaller.

c. The Guarantor Company also conducts feasibility and control over guaranteed credit. With the existence and control of two different parties, it is expected that risks can be minimized.

d. The Guarantor company will get a guarantee fee income.

It is expected that with the credit guarantee scheme for these UMKM, the UMKM that experience problems in terms of collateral can be overcome because of collateral from credit guarantee institutions. The credit channeling institution will feel safer in channeling credit to UMKM.

\section{Way to Get Business Credit}

The method used in Cibaduyut Urban Village seeking business credit must meet the conditions that become the competent parties of other parties for example:

a. The UKM submits a letter of application for KUR to the Bank by enclosing documents such as business legality, business licensing, financial records and so on.

b. The Bank evaluates / analyzes the feasibility of the UKM business based on the request of the UKM.

c. If according to the Bank, the UKM business is feasible, the Bank approves the KUR application. The decision to grant KUR is entirely the authority of the Bank.

d. Banks and UKM sign Credit / Financing Agreements.

e. UKM must pay / repay the obligation to return KUR to the Bank until paid off.

General requirements for UKM to be able to receive People's Business Credit (KUR) as follows:

a. Not receiving credit / financing from banks and / or who are not receiving Government Credit Programs / other than KUR. 
International Journal of Economics, Business and Accounting Research (IJEBAR)

Peer Reviewed - International Journal

Vol-3, Issue-3, 2019 (IJEBAR)

E-ISN: 2614-1280 P-ISSN 2622-4771

http://jurnal.stie-aas.ac.id/index.php/IJEBAR

b. Can receive consumptive credit (Home Ownership Loans, Motor Vehicle Loans, Credit Cards and other consumer credit);

c. In the event that UKM are still registered with the BI Debtor Information System, but those who have already repaid the loan, then it is necessary to have a Bank Existing Bank Certificate;

d. For Micro KUR, it is not required to check the Bank Indonesia Debtor Information System.

\section{Legal documents and permits that are minimal when the debtor submits KUR to the} Bankinclude:

a. Customer identity, such as Identity card, Driver's license, Family Card, etc.

b. Legality of business, such as deed of establishment, deed of change

c. Business licensing, such as SIUP, TDP, Domicile Decree, etc.

d. Bookkeeping or financial statements

e. Copy of collateral evidence

The KUR debtor who has already obtained and paid off KUR is allowed to apply for KUR again as long as it is still not bankable and does not exceed the KUR ceiling specified at Rp. 500,000,000; for KUR Retail and Rp. 20,000,000 for Micro KUR. The source of funds for KUR distribution is $100 \%$ (one hundred percent) sourced from the Executing Bank Funds collected from public funds in the form of demand deposits, savings and deposits (Not Aid / Grant from the Government, so that there is an Obligation to be returned) Decisions to grant KUR are fully the authority of the Implementing Bank, in accordance with the results of the business feasibility analysis of prospective debtor.

The amount of KUR loan funds that can be obtained by SMEs are:

a. Micro KUR: KUR provided with a ceiling of up to Rp. 20,000,000.

b. Retail KUR: KUR provided with a ceiling above Rp. 20,000,000, - up to Rp. 500,000,000.

Micro KUR interest rates are a maximum of or equal to $22 \%$ effective per year and the retail KUR interest rate is a maximum of or equal to $13 \%$ effective per year. The KUR debtor has the following obligations:

a. Fulfill the KUR requirements of the Executing Bank.

b. Submit collateral to the Bank.

c. Pay obligations (principal and interest) on KUR received in accordance with the repayment agreed with the Bank until the loan is repaid.

To KUR debtor can be given a term of KUR facility for a maximum of 3 years for Working Capital and a maximum of 5 years for Investment. If according to the UKM Implementing Bank it is declared Eligible and meets the KUR provisions and requirements, then the UKM can be given KUR. If the UKM debtor does not pay off the obligation of KUR, then; The Executing Bank will sell Collateral and if the collateral sales value is still insufficient, the debtor is still required to pay off the KUR; registered as a Bank Indonesia blacklist debtor.

\section{Conclusions}

Based on the results of the research and discussion described in the previous chapter, the following conclusions can be drawn: UMKM are very dominant compared to other business scale groups. In addition, the role of small businesses in absorbing labor is relatively large. So that business development is a strategic step in improving community welfare and national economic growth. 
International Journal of Economics, Business and Accounting Research (IJEBAR)

Peer Reviewed - International Journal

Vol-3, Issue-3, 2019 (IJEBAR)

E-ISN: 2614-1280 P-ISSN 2622-4771

http://jurnal.stie-aas.ac.id/index.php/IJEBAR

More than $50 \%$ of UMKM experience capital difficulties. UMKM that utilize external capital sources from credit channeling institutions are only $17.50 \%$. The reason that UMKM have not utilized credit is largely a factor of policy, requirements and high credit interest rates.

For this reason in order to further develop UMKM, there are several strategies that can be done, among others, are (1) Optimizing the role of KKMB in fostering and mentoring prospective UMKM who will apply for business loans, (2) socializing financing for profit sharing or venture capital, (3) Increasing the participation of credit guarantee institutions for UMKM prospects who are collided with collateral requirements. It is expected that with the implementation of the above strategies, the prospect of UMKM will no longer experience difficulties in terms of applying for business capital loans from the Credit Channel Institution.

Based on the results and discussion also conclusions above, suggestions can be made, as follows: Because UMKM have an important role in development, it is better for UMKM to have the full support of the government and society so that UMKM are now getting better. If UMKM are fully supported by the government and there is a reduction in unemployment due to the increasing number of UMKM.

\section{References}

Andriani, S, (2008). Analisis Faktor-Faktor Yang Mempengaruhi Volume Penyaluran Kredit Mikro, Kecil Dan Menengah (MKM) Di Indonesia. Skripsi Pada Departemen IlmuEkonomi. Fakultas Ekonomi dan Manajemen, Institut Pertanian Bogor.

BPS. (2014). Produk Domestik Bruto. (online), (http://www.bps.go.id/index.php?news=730, diakses 16 juni 2016)

Herdiansyah, Haris. (2010). Metode Penelitian Kualitatif. Salemba. Jakarta

Http://rya89.wordpress.com/(2010)/04/04/kredit-usaha-rakyat-kur/.

Iwantono, Sutrisno. (2004). Pemikiran Tentang Arah Kebijakan Pemerintah Dalam

Pengembangan Usaha Kecil Dan menegah, Jakarta Pengolahan Jurnal Teknik Industri Vol 13. No

1. Februari 2012 Hal.19

Perundang-undangan No 20 Tahun (2008) tentang UMKM

Perundang-ndangan UU No.9 tahun 1995 tentang usaha kecil

Rahmana, A dkk. (2012). Strategi Pengembangan Usaha Kecil Menengah Sektor Industri

Sri Lestari Rahayu, (2005), Analisis Peranan Perusahaan Modal Ventura Dalam Mengembangkan UKM Di Indonesia, Kajian Ekonomi dan Keuangan,Badan Pengkajian Ekonomi, Keuangan dan Kerjasama Internasional.

Sri Mulyati Tri Subari, (2004). Kebijakan dan Strategi Pengembangan Bank Indonesia dalam Mendukung Pelayanan Keuangan yang Berkelanjutan bagi Usaha Mikro, Kecil dan Menengah. Deputi Direktur Direktorat Pengawasan Bank Perkreditan Rakyat.

Sri Winarni, (2006). Strategi Pengembangan Usaha Kecil Melalui Peningkatan Aksesibilitas Kredit Perbankan. Infokop Nomor 29 Tahun XXII, 2006.

Sudaryanto dkk.(2011). Strategi Pemberdayaan UMKM Menghadapi Pasar Bebas ASEAN. Jurnal Fakultas Ekonomi Universitas Negeri Jember.

Sugiyono. (2009). Metode Penelitian Bisnis. Alfabeta. Bandung.

Tambunan, Tulus. (2009)UMKM Di Indonesia, Bogor: Ghalia Indonesia,. 